\title{
SAE FUEL CELL CODES AND STANDARDS \\ Final Scientific/Technical Report
}

November, 2007

Award Number:

Recipient:

Project Title:

Project Director:

Teaming members:
DE-FC36-02AL67609

Society of Automotive Engineers International (SAE)

Fuel Cell Codes and Standards

Patrick Davis

SAE International, SAE Fuel Cell Standards Committee (comprised of industry representatives)

Unlimited Announcement

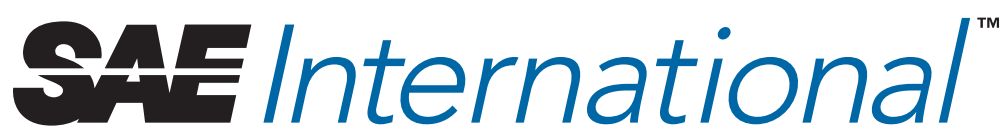




\section{Table of Contents}

$\begin{array}{lll}\text { 1. INTRODUCTION } & 3\end{array}$

2. EXECUTIVE SUMMARY 3

3. PUBLICATIONS $\quad 3$

3.1. SAE STANDARDS $\quad 3$

$\begin{array}{llr}\text { 3.2. } & \text { SAE Standards Works In Progress } & 9\end{array}$

4. SAE FUEL CELL COOPERATIVE RESEARCH 10

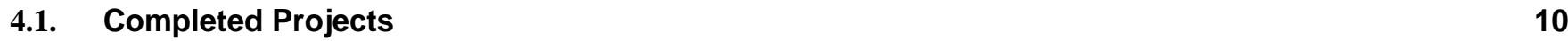

$\begin{array}{llr}\text { 4.2. } & \text { Current Projects } & 12\end{array}$

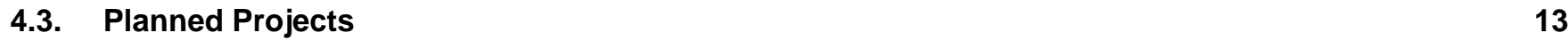

$\begin{array}{lr}\text { 5. PATENTS } & 13\end{array}$ 


\section{Introduction}

In 1999, the Society of Automotive Engineers established a committee for Fuel Cell Standards. The committee then organized into smaller working group to focus on specific issues such as fuel cell safety, fuel cell performance and fuel cell recycling. New working groups continue to form as needs arise. All working groups report to the parent Fuel Cell Standards committee.

In September 2002 SAE International was awarded funds from the Department of Energy (DOE) to continue the development of industry standards and recommended practices for fuel cell vehicles, fueling facilities and fuel transport. Also SAE was tasked with supporting and/or assisting international standards activities including International Organization of Standardization (ISO), International Electrotechnical Commission (IEC), global technical regulations (GTR), and others as directed by the DOE. Further, SAE's efforts were to the development and carrying-out of supporting research projects.

\section{Executive Summary}

The SAE Fuel Cell Standards committee and its numerous working groups have been integral in advancing hydrogen infrastructure development and to helping to enable the emergence of hydrogen as a significant energy carrier. To facilitate harmonization of all fuel cell related work the membership of the SAE Fuel Cell Standards Committee includes, but is not limited to; automotive OEMs and suppliers, national laboratories, international research organizations, and related standards development organizations.

As the lead standards development organization tasked with establishing standards for vehicle fuel cell systems and its interfaces to the vehicle, the SAE Fuel Cell Standards committee has developed and published eleven (11) technical reports of which there are eight (8) approved standards since beginning in April of 2002 and has three (3) additional standards in progress. The technical reports cover the safety aspects of fuel cell systems in vehicles, test procedures to establish the performance of the system and its components, and interface requirements. With the support of the US Department of Energy, the SAE Fuel Cell Standards Committee and its numerous working groups has facilitated consistency and harmonization among and across codes and standards developed by different organizations, shared standards development information, and promoted collaboration to minimize duplication of effort.

\section{Publications}

\subsection{SAE STANDARDS}

\subsubsection{SAE J2574 Fuel Cell Vehicle Terminology March 2002}

This SAE Information Report contains definitions for hydrogen fuel cell powered vehicle $t$. It is intended that this document be a resource for those writing other 
hydrogen fuel cell vehicle documents, specifically, Standards or Recommended Practices.

\subsubsection{SAE J2600 Compressed Hydrogen Surface Vehicle Refueling Connection Devices October 2002}

SAE J2600 applies to design, safety and operation verification of Compressed Hydrogen Surface Vehicle (CHSV) refueling connection devices hereinafter referred to as nozzle and receptacle. CHSV Refueling nozzles and receptacles shall consist of the following components, as applicable. Alternatives may be used as long as the alternative geometries shall not be interchangeable with the standard geometry specified in this SAE Standard and the standard geometry in Section 6 provides insufficient flow rates: a. Receptacle and protective cap (mounted on vehicle) (see Section 6 and 7); b. Nozzle (see Section 5).

This document applies to devices which have Working Pressures of $25 \mathrm{MPa}, 35$ $\mathrm{MPa}, 50 \mathrm{MPa}$ or $70 \mathrm{MPa}$ hereinafter referred to in this document as the following (see 9.1c): H25 - $25 \mathrm{MPa}$ at $15 \mathrm{ImDC}$; H35 - $35 \mathrm{MPa}$ at $15 \mathrm{ImDC}$; H50 - $50 \mathrm{MPa}$ at $15 \mathrm{ImDC} ; \mathrm{H} 70$ - $70 \mathrm{MPa}$ at $15 \mathrm{ImDC}$.

This document applies to nozzles and receptacles which (1) prevent hydrogen fuelled vehicles from being refueled by dispenser stations with Working Pressures higher than the vehicle; (2) allow hydrogen vehicles to be refueled by dispenser stations with Working Pressures equal to or lower than the vehicle fuel system Working Pressure, (3) prevent hydrogen fuelled vehicles from being refueled by other compressed gases dispensing stations and (4) prevent other gaseous fuelled vehicles from being refueled by hydrogen dispensing stations.

All dimensions used in this document are in metric units [International System of Units (SI)].

For the purposes of this document, compressed hydrogen gas should meet the requirements of ISO 14687 Hydrogen fuel - Product specification.

All references to pressures (MPa) throughout this document are to be considered gauge pressures unless otherwise specified. All test procedures listed in this document are design verification test procedures unless otherwise noted. All products must pass all tests to be considered to have met this design standard. Currently Under Revision

\subsubsection{SAE J2578 Recommended Practice for General Fuel Cell Vehicle Safety December 2002}

This SAE Recommended Practice identifies and defines the preferred technical guidelines relating to the safe integration of fuel cell system, fuel storage, and electrical systems into the overall Fuel Cell Vehicle. Purpose The purpose of this document is to provide introductory mechanical and electrical system safety 
guidelines that should be considered when designing fuel cell vehicles for use on public roads. Field of Application This document covers fuel cell vehicles designed for use on public roads. The committee has initiated a review to make this a system based performance standard.

\subsubsection{SAE J2594 Recommended Practice to Design for Recycling Proton Exchange Membrane (Pem) Fuel Cell System September 2003}

The purpose of this SAE Recommended Practice document is to provide a tool that helps the FC system designers and engineers incorporate recyclability into the PEM FC design process. This document was derived by considering existing recycling recommended practices then applying them to assess and evaluate the recyclability of the PEM FC system. This document should be used to continually assess the recyclability of component and assembly designs during the early design phase, in order to reach optimized recyclability, recycled content, and minimized environmental impact associated with those designs. This document defines a PEM FC rating system that assesses the ease of removal of the PEM FC system and/or components from a vehicle; then upon removal from the vehicle, the ease of recycling those components and materials. The derived rating is used as a PEM FC component design tool for continual improvement opportunities and not for purposes of calculating recyclability of the entire vehicle. While other trade-offs such as mass, piece-cost, volume, etc. must also be considered when designing these systems; they are not discussed in this document.

While there are various types of Fuel Cell architectures being developed, the focus of this document is on Proton Exchange Membrane (PEM) fuel cell stacks and ancillary components for automotive propulsion applications. Within the boundaries of this document are the: Fuel Supply and Storage, Fuel Processor, Fuel Cell Stack, and Balance of Plant, as shown.

\subsubsection{SAE J1766 Recommended Practice for Electric and Hybrid Electric Vehicle Battery Systems Crash Integrity Testing April 2005}

Electric and Hybrid Electric Vehicles contain many types of battery systems. Adequate barriers between occupants and battery systems are necessary to provide protection from potentially harmful factors and materials within the battery system that can cause injury to occupants of the vehicle during a crash. This SAE Recommended Practice is applicable to all Electric Vehicle and Hybrid Electric Vehicle battery designs, including those described in SAE J1797. The potentially harmful factors and materials addressed by this document include electrical isolation integrity, electrolyte spillage, and retention of the battery system. The purpose of this document is to define test methods and performance criteria which evaluate battery system spillage, battery retention, and electrical system isolation in Electric and Hybrid Electric Vehicles during specified crash tests. 


\subsubsection{SAE J2616 Testing Performance of the Fuel Processor Subsystem of An Automotive Fuel Cell System June 2005}

This recommended practice is intended to serve as a design verification procedure and not a product qualification procedure. It may be used to verify design specifications or vendor claims. Test procedures, methods and definitions for the performance of the fuel processor subsystem (FPS) of a fuel cell system (FCS) are provided. Fuel processor subsystems (FPS) include all components required in the conversion of input fuel and oxidizer into a hydrogen-rich product gas stream suitable for use in fuel cells.

Performance of the fuel processor subsystem includes evaluating system energy inputs and useful outputs to determine fuel conversion efficiency and where applicable the overall thermal effectiveness. Each of these performance characterizations will be determined to an uncertainty of less than $+/-2 \%$ of the value. The method allows for the evaluation of fuel processor subsystems for two general cases. - Compare fuel processors with different designs (e.g., catalytic partial oxidation reforming, autothermal reforming or steam reforming) on a common basis where no specific fuel cell system design has been identified. Assess the performance of a specific fuel processor in the context of a specific fuel cell system design.

This document applies to all fuel processor subsystems for transportation applications regardless of fuel processor type, fuel cell type, electrical power output, thermal output, or system application (propulsion or auxiliary power unit (APU)). For example, the fuel processor subsystems associated with proton exchange, molten carbonate and solid oxide fuel cells can differ due to the requirements of the fuel cells themselves. Performance of the fuel processor subsystem, and preprocessor if applicable, is evaluated.

A stand alone fuel processor system or even the primary reactor (e.g., autothermal, partial oxidation or steam reforming reactor) of a fuel processor subsystem that would normally be integrated into a fuel cell system can be evaluated. The fuel processor together with the preprocessor (if required) converts the fuel (gasoline or other liquid hydrocarbon) to a reformate gas consisting largely of $\mathrm{H} 2, \mathrm{CO}, \mathrm{CO} 2$, $\mathrm{H} 2 \mathrm{O}$ and N2 (if air is used). After the fuel processor subsystem, reformate gas typically contains only trace levels of carbon bearing components higher than $\mathrm{C} 1$. The FPS would be evaluated in a test facility that is designed to evaluate a standalone component rather than a portion of the reformer such as a specific catalyst or a particular vessel design.

Any fuel(s) mutually agreed to by the test parties can be used such as 1) straight run gasoline (EPA Fuel- CARB reformulated gasoline Tier II, 30 ppm sulfur), or 2) methanol or 3) hydrocarbon fuel such as iso-octane, naptha, diesel, liquefied natural gas (LNG) or LPG (propane), etc. The procedures provide a point-in-time evaluation of the performance of the fuel processor subsystem. Steady state and transient (start-up and load-following) performance are included. 
Methods and procedures for conducting and reporting fuel processor testing, including instrumentation to be used, testing techniques, and methods for calculating and reporting results are provided. The boundary limits for fuel and oxidant input, secondary energy input and net energy output are defined. Procedures for measuring temperature, pressure, input fuel flow and composition, electrical power and thermal output at the boundaries are provided. Procedures for determination of the FPS performance measures such as fuel processor efficiency and cold gas efficiency at a rated load or any other steady state condition are provided. Methods to correct results from the test conditions to reference conditions are provided. SI units are used throughout the recommended practice document.

\subsubsection{SAE 2719 Information Report on the Development of a Hydrogen Quality Guideline for Fuel Cell Vehicles November 2005}

This document is an information report on the development an evolving $\mathrm{H} 2$ Fuel Quality guideline for the vehicular refueling interface, which will mature as technology advances toward commercial feasibility. The latest guideline will form the basis of a proposed standard for commercial hydrogen fuel Purity for $\mathrm{H}$ powered vehicles, possibly including ICE's.

3.1.8. SAE J2572 Recommended Practice for Measuring Fuel Consumption and Range of Fuel Cell and Hybrid Fuel Cell Vehicles Fuelled by Compressed Gaseous Hydrogen August 2006

This SAE Recommended Practice establishes uniform procedures for testing fuel cell and hybrid fuel cell electric vehicles, excluding low speed vehicles, designed primarily for operation on the public streets, road and highways. The procedure addresses those vehicles under test using compressed hydrogen gas supplied by an off-board source or stored and supplied as a compressed gas onboard. This practice provides standard tests that will allow for determination of fuel consumption and range based on the US Federal Emission Test Procedures, using the Urban Dynamometer Driving Schedule (UDDS) and the Highway Fuel Economy Driving Schedule (HFEDS). Chassis Dynamometer test procedures are specified in this document to eliminate the test-to-test variations inherent with track testing, and to adhere to standard industry practice for fuel consumption and range testing. Communication between vehicle manufacturer and the governing authority is essential when starting official manufacturer in-house and official government confirmatory testing that incorporates this practice.

\subsubsection{SAE J2760 Pressure Terminology Used in Fuel Cells and Other Hydrogen Vehicle Application May 2006}

The purpose of this technical information report is to disseminate definitions for pressurized systems and containers prior to the release of SAE J2579 ensuring 
other technical groups are aware of the information. SAE J2579 is being developed by the SAE Fuel Cell Vehicle (FCV) Safety Working Group (SWG) to provide recommended practices for Fuel Systems in Fuel Cell and Other Hydrogen Vehicles.

\subsubsection{SAE J2617 Recommended Practice for Testing Performance of PEM Fuel Cell Stack Sub-system for Automotive Applications November 2007}

This recommended practice is intended to serve as a procedure to verify the design specifications or vender claims of any PEM (Proton Exchange Membrane) type fuel cell stack sub-system for automotive applications. In this document, definitions, specifications, and methods for the performance characterization of the fuel cell stack sub-system are provided. The performance characterization includes evaluating electrical outputs and controlling fluid inputs and outputs based on the test boundary defined in this document. In this recommended practice, a typical fuel cell stack sub-system includes the following: - Fuel cell stack(s) - An Assembly of membrane electrode assemblies - (MEA), current collectors, separator plates, cooling plates, manifolds, and a supporting structure. - Connections for conducting fuels, oxidants, and exhausts. - Electrical connections for the power delivered by the stack sub-system. - Devices for monitoring electrical loads, which are for interface to the fuel cell system (FCS). - Devices for monitoring cell voltage (Not all stacks are designed to read every cell voltage.) - Additional connections for conducting additional fluids, such as cooling media and inert gas - Instrumentation for detecting normal and/or abnormal operating conditions. - Enclosures or pressure vessels, and ventilation systems. Not included in the sub-system are the following: - Fuel and air processors - Thermal management system - Power conditioner and distributor - Controllers The goal of this recommended practice is to provide a method for users to conduct fuel cell stack sub-system tests on a common basis. This allows the comparison of fuel cell stack sub-systems with different designs where no specific fuel cell system design has been identified. Alternatively, the performance of a specific fuel cell stack sub-system can be assessed in the context of a specific fuel cell system design based on the agreement of the testing parties.

\subsubsection{SAE J2799 70 MPa Compressed Hydrogen Surface Vehicle Fuelling Connection Device and Optional Vehicle to Station Communications May 2007}

This technical information report specifies a guideline for the hardware requirements for fueling a Hydrogen Surface Vehicle (HSV) with compressed hydrogen storage at a Nominal Working Pressure of 70MPa. It contains a description of the receptacle geometry and optional communication hardware and communications protocol to refuel the HSV. The intent of this document is to enable harmonized development and implementation of the hydrogen fueling interfaces. It is intended to be utilized for the hydrogen vehicle field evaluation until enough information is collected to enable standardization. The receptacle portion of this TIR is to be reevaluated utilizing international field data in approximately 2 years and subsequently superseded by $\mathrm{J} 2600$ in the 2009 timeframe. At that time, input would be gathered from international locations through the representation in the SAE Fuel 
Cell Committee in order to confirm the final decision regarding the direction of the receptacle and communications standard. The communications portion of the TIR is also to be reevaluated utilizing international field data and subsequently superseded by J2601. It is anticipated that the communications protocol and hardware could be standardized before the above mentioned timeframe. It is not the intent of this document to imply a position regarding the commercial fueling protocol, communications, or non-communication strategy, but simply serves as a reference for the receptacle hardware and IRDA communications if this strategy is selected. In addition, it is not intended to be referenced by other Standard and/or Code organizations.

\subsection{SAE Standards Works In Progress}

\subsubsection{SAE J2579 Technical Information Report for Hazardous Fluid Systems in Fuel} Cell Vehicles

The purpose of this document is to define design, construction, operational, and maintenance requirements for hydrogen storage and handling systems in on-road vehicles. Performance-based requirements for verification of design prototype and production hydrogen storage and handling systems are also defined in this document. Complementary test protocols (for use in type approval or selfcertification) to qualify designs (and/or production) as meeting the specified performance requirements are described. Crashworthiness of hydrogen storage and handling systems is beyond the scope of this document. SAE J2578 includes requirements relating to crashworthiness and vehicle integration for fuel cell vehicles. Note: Ultimate design qualification for crash impact resistance is achieved by demonstrated compliance of the vehicle with applicable regulations.

\subsubsection{SAE J2783 Liquid Hydrogen Surface Vehicle Refuelling Connection Devices}

\subsubsection{SAE J2601 Compressed Hydrogen Vehicle Fueling Communication Device}

The working group is refining the fueling scope with data being gathered from a variety of demonstration sources including transit bus coverage and coordination with $\mathrm{CaFCP}$ guideline efforts.

\subsubsection{SAE J2722 Recommended Practice for the durability testing of testing of PEM Fuel Cell Stacks}

This recommended Practice is intended to serve as a procedure to verify the durability specifications or vender claims of any PEM Proton Exchange Membrane type fuel cell stack sub system for automotive applications. In this document, definitions, specifications, and methods for the durability characterization of the fuel cell stack sub system are provided. The durability characterization includes evaluating electrical outputs and other stack characteristics over time while 
controlling fluid inputs and outputs based on the test boundary defined in this document.

\section{SAE Fuel Cell Cooperative Research}

\subsection{Completed Projects}

\subsubsection{Root Cause Analysis and Report for CNG Tank Field Failures}

Powertech Labs, Inc. was contracted to examine the Powertech CNG cylinder field failure database to determine if there are any evident trends. The scope of the investigation was limited to incidents involving catastrophic rupture of cylinders, although major leaks attributed solely to the cylinder were included. Currently, there are over 6.1M CNG vehicles in the world (www.IANGV.org). Since 2000, there have been 26 CNG cylinder failures.

The approach taken was to tabulate the data in reverse chronological order, fields included were:

- Date

- Location

- Number of cylinders involved

- Cylinder manufacturer

- Cylinder design type

- Vehicle type

- Source of the data

- Brief description of the incident

- Cause of failure

- Failure mode category

Single cylinder failures attributable to "rupture failure mode" were noted with two exceptions:

- Type 3 glass cylinder merely leaked due to SCC

- Type 4 carbon cylinder leaked after impact with overpass

Multiple cylinder failures attributable to "leakage failure mode":

- Type 1 steel pinhole leaks $(<50)$

- Type 4 plastic liner leak incidents (100's)

The data was then classified according to eight unique failure causes:

- $\quad$ Mechanical Damage - External abrasion and/or impact

- Environmental Damage - External environment assisted, typically SCC

- $\quad$ Overpressure - Faulty fueling equipment or faulty CNG cylinder valves

- $\quad$ Vehicle fire - Faulty PRDs or lack of PRDs; localized fires

- $\quad$ Plastic Liner Issues - Man. defects incl. cracking at end boss/liner interface, flawed welds, liner seal failures 
- $\quad$ Metal Liner Issues - Man. defects incl. pinhole leaks, laminations, poor heat treat practice

- $\quad$ User Error - Test facility error

- Unknown Cause - Limited or no data available

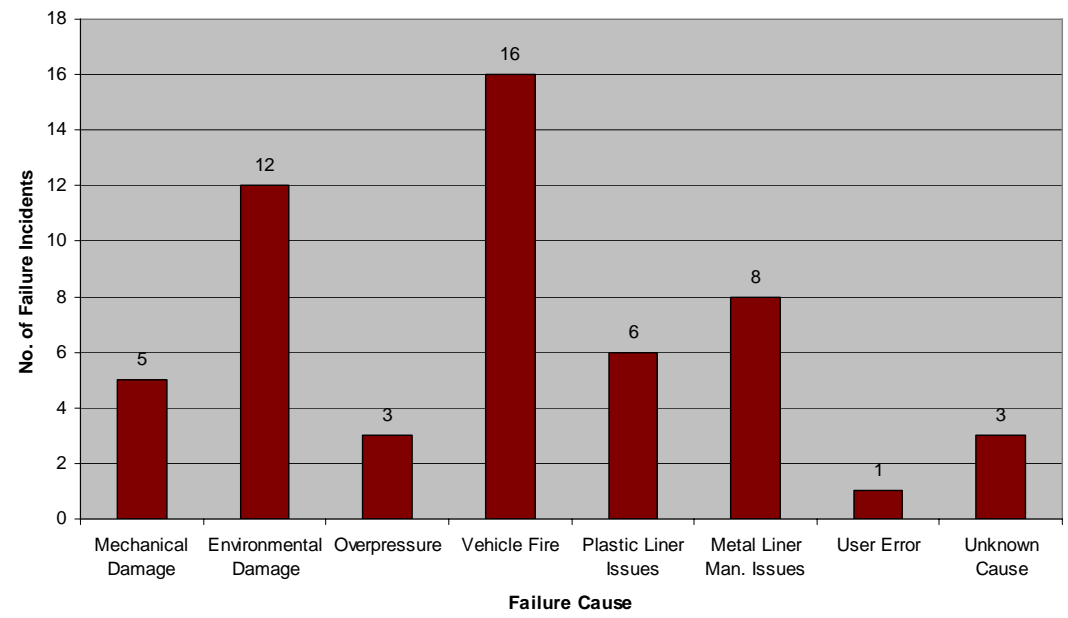

Figure1.0 Failure Incidents by Failure Cause

The investigation of failure incidents reported by cylinder type revealed:

- Type 1 steel cylinders are involved in nearly 50\% of failure incidents

- Aftermarket vehicles represent just over $50 \%$ of failure incidents

- Data is related as most aftermarket conversions employ low cost/readily available Type 1 cylinders

- Many of the installations less likely to follow sound engineering practice (regarding use of standards, materials/workmanship quality, installation codes, maintenance/inspection procedures)

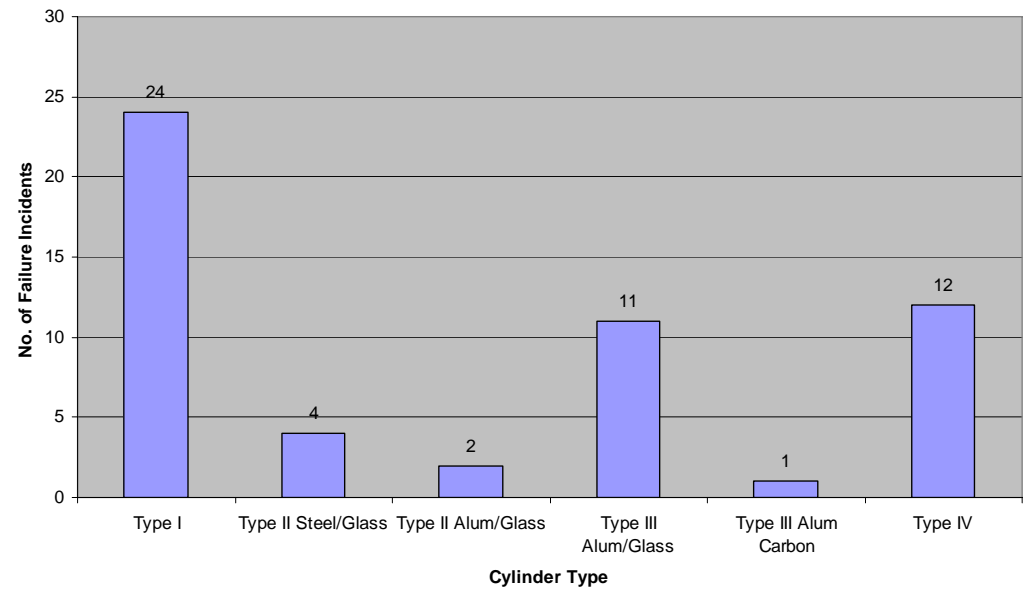

Figure 2.0 Failure Incidents by Reported by Cylinder Type 


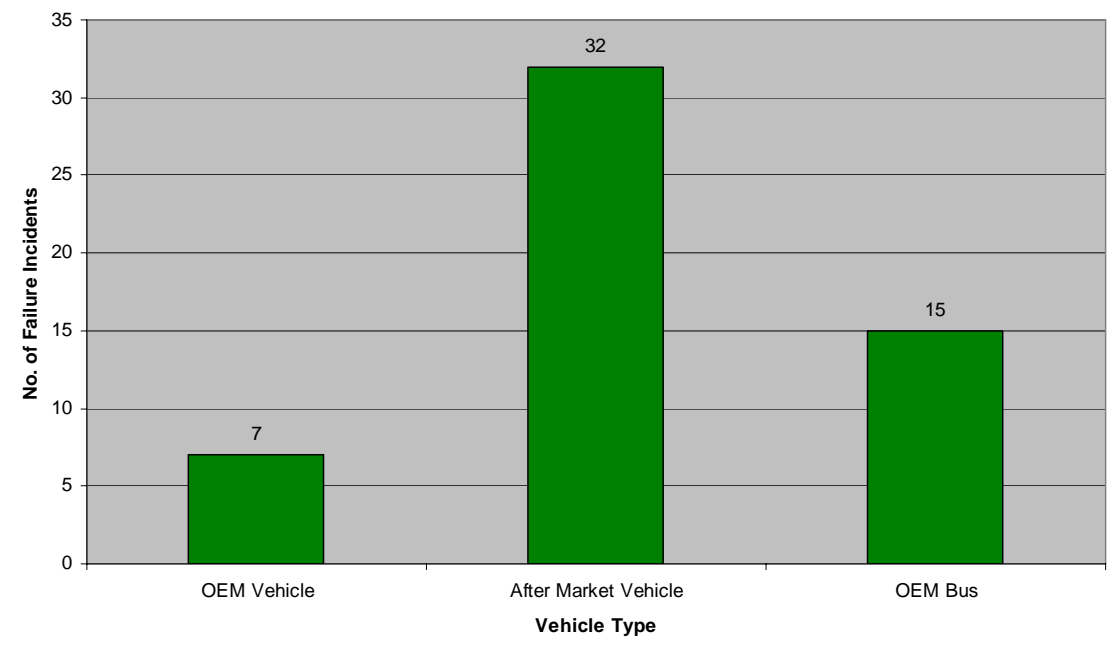

Figure 3.0 Failure Incidents by Reported by Vehicle Type

\section{Conclusions}

$>$ Vehicle fire is the leading cause of CNG cylinder failures - at least 4 out of 16 due to localized fire

$>$ Environmental damage is the second leading cause of CNG failures, but cylinder standards have adequately addressed this failure cause

$>$ Less than $25 \%$ of the CNG cylinder failures were attributed to Type $3 / 4$ cylinders (13 incidents):

- Only 5 incidents involved rupture failure mode

- Of these 5 incidents, 4 involved vehicle fires

\subsection{Current Projects}

\subsubsection{Evaluation of the Performance Verification (Design Qualification) Test for Compressed Hydrogen Containment Systems}

Qualification and routine testing shall be performed on hydrogen containment vessels designed for $70 \mathrm{MPa}$ service in order to validate proposed methods. Current proposed test methods are defined in a draft version of SAE TIR J2579, section 5.2.6 and appendix C. Status: This project has been approved and the testing is underway. 


\subsection{Planned Projects}

4.3.1. Performance evaluation of $70 \mathrm{MPa}$ Hydrogen Station Breakaways, Hoses, fittings and Nozzles

The performance of existing hydrogen station dispenser breakaway to nozzle assemblies shall be examined against current draft standards (ANSI/CSA HGV4 series) and to tests designed to recreate actual service conditions. The hardware shall be examined on a component level through a series of pre-qualification tests for baseline performance (similar to that already performed on nozzles for the SAE J2799/J2600 committee). Following the baseline component level testing, several "real life" tests will be performed to evaluate conditions expected in service that are not necessarily covered in standards. The results of this study will be shared with the SAE Fuel Cell committee and the CSA America HGV committee. Status: This project proposal is being reviewed by NREL staff.

\subsubsection{Suitability of Alternative Test Gases for Leak Testing Hydrogen Refueling Devices}

The goal of this project is to develop alternatives to the use of "pure" hydrogen gas when performing leak test measurements of compressed hydrogen refueling devices. The successful outcome will lead to the development of alternative gas combinations for use a nearly every hydrogen based standard currently under development. Status: This project proposal is being developed.

\section{Patents}

None 